\title{
Profiles of Chicano educational opportunity 1950-1980 the significance of teacher expectations
}

\author{
Silvia L.M. Martinez
}

Follow this and additional works at: https://digitalscholarship.unlv.edu/jpme

\section{Repository Citation}

Martinez, Silvia L.M. (2010) "Profiles of Chicano educational opportunity 1950-1980 the significance of teacher expectations," Journal of Praxis in Multicultural Education: Vol. 5: No. 1, Article 8.

DOI: 10.9741/2161-2978.1032

Available at: https://digitalscholarship.unlv.edu/jpme/vol5/iss1/8

This Article is protected by copyright and/or related rights. It has been brought to you by Digital Scholarship@UNLV with permission from the rights-holder(s). You are free to use this Article in any way that is permitted by the copyright and related rights legislation that applies to your use. For other uses you need to obtain permission from the rights-holder(s) directly, unless additional rights are indicated by a Creative Commons license in the record and/ or on the work itself.

This Article has been accepted for inclusion in Journal of Praxis in Multicultural Education by an authorized administrator of Digital Scholarship@UNLV. For more information, please contact digitalscholarship@unlv.edu. 


\title{
Profiles of Chicano Educational Opportunity 1950-1980 The Significance of Teacher Expectations
}

\begin{abstract}
Silvia L.M. Martinez
A classified ad was printed in a Southern California newspaper requesting Chicanos who attended high school between 1950 and 1980 to discuss their school experiences. Eight interviews were conducted; one participant was a college graduate, two others were high school graduates, and the others dropped out of high school to work or start a family. The interviews illuminated how the educational system, namely teachers' expectations, affected the academic aspirations and achievements of the participants. Interview results showed that the lack of culturally affirming relationships with teachers hindered most interviewees' ability to make connections between hard work in school and future social and economic benefits.
\end{abstract}

This study focuses on how Southern California Chicano students who attended high school between 1950 and 1980 perceived their educational opportunities and interpreted their experiences in school. Oral history interviews inform this study's focus on how schools, particularly teachers' expectations, affected the academic aspirations and attainment of Chicano high school students. The theme of low expectations presented itself as a critical force in the educational success and failure of the interviewees, affecting the value they placed on education and raising questions concerning their place within schools. For these students, low teacher expectations functioned as a form of discouragement, negatively affecting academic goals and high school graduation. Nevertheless, those who did graduate from high school felt their teachers were their main source of encouragement and motivation to persist. The linchpin of these two different experiences was the ability of the interviewees to negotiate academic achievement with their ethnic identity in response to actions and reactions of their teachers.

\section{The Teacher Expectation Effect}

The teacher expectation effect holds that teacher behaviors, biases, and interactions produce student academic success and failure; and is one of the many institutional explanations of the achievement gap (Babad, Inbar, \& Rosenthal, 1982; Brophy, 1983; Dusek, 1985; Garcia, 2001; Hallinan, 2001; Jensen \& Rosenfeld, 1974; Kloosterman, 2003; Noguera \& Wing, 2006; Valencia, 2002; Walker, 1987). Researchers have found that teachers exhibit 
lower expectations for poor students, students of color, and those with prior histories of low achievement. Low expectations result in teachers supporting and challenging these students less, a pattern that ultimately affects persistence, achievement and attainment (Baron, Tom, \& Cooper, 1985; Brophy, 1983; Diamond, Randolph, \& Spillane, 2004; Dusek, 1985; Jensen \& Rosenfeld, 1974; Jussim, Eccles, \& Madon, 1996; Murgia and Telles, 1996).

Additionally, researchers have repeatedly shown that teachers have tended to give higher ratings and more praise and encouragement to White students than to students of color regardless of performance (Baron et al., 1985; Diamond et al., 2004; Jensen \& Rosenfeld, 1974; Murgia and Telles, 1996). Moreover, it is not just that teachers display lower expectations for some students; it is that students are aware of the lower expectations, which affects their self-concept and motivation (Brattesani, Weinstein, \& Marshall, 1984; Dusek, 1985; Weinstein \& Mckown, 1998). Thus, teachers' expectations affect the culture of schools - teachers often provide messages to students regarding who is included or excluded (Buriel, 1981; Dusek, 1985; Hallinan, 2001; Patthey-Chavez, 1993; Pizzaro, 2005; Stanton-Salazar \& Dornbusch, 1995).

Although there is extensive research regarding the teacher expectation effect, questions remain about appropriate design and methodology. Questions also remain as to whether teacher expectations cause achievement or accurately predict it, and whether negative or positive expectations are more powerful (Brophy, 1983; Jussim, 1991; Jussim et al., 1996; Jussim \& Harber, 2005). In Jussim and Harber's (2005) review of these issues, they contended that there are effects of teacher expectations on student achievement, yet the effects more often tend to be small and do not accumulate over time; although larger effects continue to be found with students from impoverished backgrounds, students of color, and students with histories of underachievement.

\section{Methods}

A classified ad was printed in the Inland Valley Daily Bulletin published in Ontario, California, requesting Chicano individuals who attended high school between 1950 and 1980 to discuss their high school experiences. ${ }^{2}$ The Daily Bulletin has a daily circulation of 60,000 and serves the Inland Empire region of Southern California. Historically and today, the Inland Empire region maintains a high concentration of Chicanos, including a steady flow of Mexican immigrants, which is why this area was selected for study. The newspaper advertisement led to eight interviews. Prior to the interview, the participants received an informed consent form detailing the purpose of the study; interview

\footnotetext{
${ }^{2}$ In 2007, the Human Subjects Committee of Lawrence at the University of Kansas granted approval
} for the researcher to interview and collect data. The ad offered a $\$ 10.00$ gift card for participation. 
process and procedures; potential risks and benefits; confidentiality, privacy, and voluntary status; and contact information for the researcher. The interviews were one-on-one and focused on participants' educational attainment, experiences in school, and views concerning the importance of education through a semi-structured interview protocol. The constant comparative method was used for the data analysis of the interview transcriptions (Boeije, 2002; Charmaz, 2006; Glaser, 1992). To increase confidence in the validity of the results, random member checking was also used for representativeness and accuracy. ${ }^{3}$

\section{Uses and Limitations of Oral History}

Oral history was chosen as the method of study to bring a new perspective in understanding the past. In the vein of oral history theory, the ideas of "history from below" and "hidden from history" (Bhattacharya, 1983; Lynd, 1993) were used to uncover the voices of Chicanos who attended high school between 1950 and 1980. The prevailing use of oral history has been to serve as a piece of historical evidence that fills gaps in the written record, illuminates the experiences of a time in question, and corroborates or discredits other sources of information (Dougherty, 1999; Thomson, 1998, 2007), and the interviews did perform each of these roles.

The findings are not to be generalized, although they were consistent with those of related research on the discrimination and marginalization of Chicano students (see work by Ruben Donato, Gilbert Gonzalez, Victoria-Maria MacDonald, and Guadalupe San Miguel). Even so, the difficult task in analyzing oral histories is sorting the significant from the insignificant anecdotes as well as the truth from the embellished memories (Dougherty, 1999; Thomson, 1998, 2007).

An important limitation is that the study included only Chicano individuals who elected to participate in the study, which may be a concern if the interviewees had not displayed a broad range of academic experiences and attainment. Logic would hold that those who may not have enjoyed school or done well in school would not have wanted to participate. But this was not the case, as can be seen in the varying school outcomes in the sample. Additionally, researchers are concerned about the undeniable limitations that lie with selfreported data, yet without direct contact with the individuals themselves, the experiences and stories could not have been documented effectively. The themes

\footnotetext{
${ }^{3}$ All information gathered in the interviews was reported accurately, as the accounts given were recorded. In cases where clarity of the content was uncertain, grammar and sentence structure were corrected.
} 
presented in this paper were chosen because, as the participants explained, they reflected the most important experiences that affected their academic life and educational attainment. The study was designed diligently and respectfully to adhere to the spirit of the interviews.

\section{Interview Participants}

The interview participants consisted of two women and six men who considered themselves Chicanos; all were born in the U.S. and were from working-class families. All of the interviewees attended public schools and described their high schools as predominately Chicano and White, with mostly White teachers. Highlighted interview participant descriptors can be found in

Table 1.

Table 1

Interview Participant Descriptors

\begin{tabular}{|c|c|c|c|c|}
\hline Name & Occupation & $\begin{array}{l}\text { Birth } \\
\text { Year }\end{array}$ & $\begin{array}{l}\text { Educational } \\
\text { Attainment }\end{array}$ & $\begin{array}{l}\text { Children's } \\
\text { Attainment }\end{array}$ \\
\hline José & $\begin{array}{lr}\text { Retired School } \\
\text { District Grounds } \\
\text { Supervisor }\end{array}$ & 1936 & HS Graduate, 1954 & $\begin{array}{l}3 \text { HS Graduates \& } \\
2 \text { College Graduates }\end{array}$ \\
\hline Richard & Auto Mechanic & 1938 & HS Drop-out, 1956 & No Children \\
\hline Anna & $\begin{array}{lr}\text { Retired } & \text { School } \\
\text { District } & \text { Food } \\
\text { Supervisor } & \end{array}$ & 1940 & HS Drop-out, 1956 & $\begin{array}{l}4 \text { HS Graduates \& } \\
2 \text { College Graduates }\end{array}$ \\
\hline Carlos & $\begin{array}{l}\text { Newspaper } \\
\text { Distributor }\end{array}$ & 1941 & HS Drop-out, 1957 & 2 HS Drop-outs \\
\hline Philip & $\begin{array}{l}\text { Phone Company } \\
\text { Fiber Splicer }\end{array}$ & 1946 & HS Graduate, 1964 & $\begin{array}{l}1 \text { HS Graduate \& } \\
3 \text { College Graduates }\end{array}$ \\
\hline Bernicio & Auto Mechanic & 1953 & HS Drop-out, 1967 & $\begin{array}{l}1 \text { HS Drop-out \& } \\
1 \text { College Graduate }\end{array}$ \\
\hline Juanita & $\begin{array}{l}\text { Manufacturing } \\
\text { Material Handler }\end{array}$ & 1956 & HS Drop-out, 1973 & $\begin{array}{l}2 \text { HS Drop-outs \& } \\
1 \text { HS Graduate }\end{array}$ \\
\hline Ed & $\begin{array}{l}\text { Human Resources } \\
\text { Manager }\end{array}$ & 1957 & $\begin{array}{l}\text { HS Graduate, } 1975 \\
\text { College Graduate, } \\
1979\end{array}$ & 2 College Graduates \\
\hline
\end{tabular}


Martinez: Profiles of Chicano educational opportunity 1950-1980

\section{Findings: The Significance of Teacher Expectations}

Low teacher expectations arose consistently throughout the interviews, despite the diverse educational backgrounds and attainment of the interviewees. None of the participants felt overtly discriminated against while in school. But silently and covertly they felt they were not valued in the school system because of their ethnic background, especially by teachers who they felt underestimated their educational possibilities. This inconsistency speaks to the ways that subtle racism occurs, as noted by Pizzaro (2005), who suggested that teachers holding Chicano students to a lower standard/expectation is one example of subtle racism that partially explains students' academic underachievement. Teachers' low expectations of participants based on their Mexican heritage, more than any overt act of discrimination, resulted in most of the them devaluing education and the opportunities schooling could have afforded them. The significance of teacher expectations was identified in connection with three themes: Englishonly policies, tracking and career counseling, and "acting White."

\section{English-Only Policies}

Historians have argued that the enactment of English-only policies served to discriminate against Chicano students and families, consequently undermining their cognitive development and the value placed on education (Gonzalez, 1990; San Miguel, 2001). In fact, in the early grades many of the participants felt their use of Spanish was the one feature that distinguished them most from the White schoolchildren. José described this perception in regard to a "special note" that came home from his first grade teacher.

The note said that my parents should stop speaking Spanish to me because it will make learning English and school more difficult. . . . They had my aunt help me learn English. . . . I know that it made me feel embarrassed. I'm not sure if I was embarrassed about my parents only speaking Spanish or embarrassed by my teacher; either way it made me look at school differently.

According to Gonzalez (1990), teaching pedagogy prior to the 1960s was based on the notion that maintaining the Spanish language slowed assimilation and lowered the possibility of academic success within schools. This would explain the note José and his family received. However, current research notes the importance of maintaining Spanish while learning English for both academic success and identity cultivation (Portes \& Rumbaut, 2001; Tollefson, 2002). 
Like José, several of the other interviewees felt stigmatized by their teachers because of their Spanish-speaking background, making language abilities a defining factor in their schooling. Indeed, several felt scared and inadequate in the classroom, as described by Carlos who began his first day of school speaking only Spanish:

I remember walking into the classroom and hearing all the English-speaking children, which scared me. The teacher was very nice and greeted me in Spanish but then told me that I couldn't speak Spanish in her class, so the rest of the day I didn't say one word . . . once I got home I told my parents that my teacher said I couldn't come back to school until I knew English. . . . They hired a neighbor to teach me [and my siblings] English. . . . I only went back to school when my little sister went. . . . I was too scared of what my teacher would do if I didn't speak English.

As for Phillip, he felt his teachers overlooked his academic abilities and weaknesses because of his lack of English proficiency:

I had a reading problem early on and probably should have been held back twice, but the teachers kept pushing me through even though I couldn't read well. The teachers never really told me I was doing badly, but I could tell by how well most of the other students read. . . I still wonder why they didn't tell my parents something.

These feelings of inadequacy and embarrassment ran through each of the interviews. Low expectations seemed to be covertly couched in terms of "language deficiencies," leading to low academic confidence and skepticism regarding the advantages of schooling.

Although most of the interviewees said students could speak Spanish on the playground or during lunch, many were afraid of doing so in front of teachers. Bernicio, Juanita, and Phillip each discussed how this fear affected their attitude about school because they had been disciplined by teachers and ostracized by other students for speaking Spanish. Bernicio shared, "If you spoke Spanish at school, the teachers would immediately and harshly correct you ... and students would tease you. . . . I remember wanting to hide." And as Philip noted:

I remember when I spoke Spanish in school my teachers would punish me by pulling my ears, so I quickly learned to stop; in fact, I hardly spoke at all after that, Spanish or English. School became a place where I didn't feel like I could be myself. 
These experiences of teacher stigmatization are typical in the research about Spanish-speaking students. Fernandez and Nielsen (1986) found that teachers penalized Spanish-speaking students for their cultural distinctiveness by discounting their abilities and by expecting less of them academically, which correspondingly led to low levels of effort by students, as described by Bernicio and Phillip. Correspondingly, Laosa (1977) also found that teachers' disapproving attitudes towards Chicano schoolchildren hinged on language. Students with limited English proficiency were more likely to experience negative teacher-student interactions than Chicano children who were proficient English speakers.

\section{Tracking and Career Counseling}

Gonzalez (1990) argued that school administrators and teachers pushed vocational education tracks for Chicano children, based on the belief that manual labor was most appropriate for Chicanos. These low expectations resulted in Chicano students being overrepresented in low-ability classrooms and underrepresented in high-ability classrooms (Arias, 1986; Carter, 1970; Carter \& Segura, 1979; Contreras \& Valverde, 1994; Donato, 1997, 2007; Gonzalez, 1990, 1999; Oakes, 1992). Hallinan (2001) explained that these lowability tracks have detrimental effects on students' self-esteem and self-image. They also lead to inferior instruction, less time on task, more classroom distraction, and generally a less serious academic climate, tendencies, which were apparent in many of the interviews. As Richard noted, "I took the regular classes and shop classes. I learned a lot . . . but I could have learned more if the teachers cared about us as much as they did about the White students going to college." Richard's feelings clearly tie in to the second-class status Chicano students experience in school, as described by Carter and Segura (1979): "Tracking and other practices that isolate Mexican children not only discouraged equal-status interaction between them and their Anglo peers but it also reinforced the stereotypes each groups holds of the other . . . and strengthened the teachers' stereotypes" (pp. 236-237).

Furthermore, Chicano students tended to have little to no career counseling that justified the general education and vocational education tracks in which they were placed (Cortese, 1992; Medina \& Luna, 2000). Bernicio said his school counselor strongly urged him to follow the vocational technical coursework, but was unsure as to why the counselor thought he would excel more in that program versus a college preparatory program. While neither Richard nor Phillip was tracked, they received no career counseling, and Anna too said she received no counseling, either for coursework or for careers. She noted, "No one ever told me these are the classes you need to take to graduate. . 
. . I was awful at reading; my teachers thought it was because I was Mexican, but I didn't even speak Spanish."

Gonzalez (1990) also described low teacher expectations as a manifestation of the biased assumption that Chicano children gravitated toward employment patterns similar to their parents - thus, vocational education would be of greater value to their future careers than would a liberal arts education. Correspondingly, Juanita believed she and other Chicano students were steered away from the general and pre-college courses because of assumptions about their Mexican parents' occupations. She said, "Our teachers didn't discriminated against us . . . they never told us we couldn't do something because we were Mexican; they just thought we were going to end up with jobs like our parents." Carter and Segura (1979) noted that "the public and educators alike assumed that low socioeconomic status ... were the natural and understandable consequences of racial or cultural inferiority" (p. 14). Much of the research has indicated that schools were educating Chicano students for manual labor, as evidenced by the overemphasis on vocational education (Arias, 1986; Carter, 1970; Carter \& Segura, 1979; Gonzalez, 1990, 1999; San Miguel, 1987, 2001).

The low expectations Chicano students experienced in schools were further complicated for Chicanas. As Pizzaro (2005) points out, Chicanas often face three levels of discrimination in their schooling: ethnic, class, and gender. Anna noted:

The teachers just didn't think you could do the same work as men, in the classroom or in work. And they didn't think much of you because you were Mexican, and then of course they thought all Mexicans were poor. . . . I really felt ignored in school by the teachers for being a Mexican girl, but what could I have done about it? ... They just didn't expect as much from us.

For the women, the status of being Mexican, female, and working-class clearly affected how they interpreted their treatment in school and the expectations teachers had of them. These experiences reinforced societal racial/ethnic, class, and gender prejudices, resulting in feelings of second-class status for these women.

\section{"Acting White"}

The theme of "acting White" arose in several interviews as well. Those interviewees who dropped out of school discussed how only the White students and the Chicano students who acted White performed well in school and participated in school activities. These perceptions are aligned with the behaviors of "acting White" as described by Fordham and Ogbu (1986). They defined "acting White" as the perception by peers that a student of color who is 
successful in school is "selling out." Research has suggested that students who choose to "act White" often experience the consequences of being labeled traitors or even experience physical threats. Other researchers, however, argue that it depends on the school climate; many students of color may not have had to make ethnic compromises to succeed in school (Flores-Gonzalez, 1999; Foley, 1991; Matute-Bianchi, 1986). For the interview participants, "acting White" had less to do with academic achievement and more to do with "airs" in school, that is, students acting as if they were "better" than their culture and neighborhood.

Although Ed succeeded in school, he did not feel labeled as "acting White," nor did he feel that he needed to make ethnic concessions to fit in with the Mexican culture of his peers. He believes this was possible because he was an athlete and well liked by both students and teachers, which mitigated his need to circumvent his ethnic identity to be academically successful. However, Ed did believe that teachers promoted ethnic compromises, since they tended to be more supportive of Chicano students who "acted White":

You know the teachers never said you should act White or dress White, but the sentiment given was that as a Chicano your life would be easier . . . if you acted more White. If you didn't, you would easily find yourself labeled, stereotyped, and not encouraged in school; . . . the hidden message was don't wear beanies or Pendleton plaid shirts, and certainly don't grow a mustache because that meant you were trouble.

Other interviewees perceived the "acting White" concept as a move toward assimilation. They said teachers suggested they wear certain clothing and hairstyles, use particular hair and grooming products, and refrain from speaking Spanish, all to assimilate them and make them White. As a consequence of not following these suggestions, the participants felt that teachers ignored them and expected less of them because they appeared to be "stereotypical Chicanos." These feelings echo Goffman's (1963) work on stigma, where he finds that "membership in a despised group" disqualifies one from social acceptance, resulting in repeated confrontations of rejection. In this regard, Matute-Bianchi (1986) documented how both teachers and students stigmatized students who self-identified as Chicano as uninterested and unmotivated in school, and also as ignorant of educational opportunities. This was confounding to many teachers. It seemed obvious to them that students would benefit from changing their attitudes and dress, but to students it seemed obvious that they must reject a system not congruent with their ethnic identity and style.

\section{A Profile of Success in School}


Ed was the one interviewee who graduated from high school and went on to earn a bachelor's degree; he represents the most educationally successful participant in the study. He was also the youngest of the interview participants, graduating from high school in 1975. In this time period, college-going rates were increasing among the Chicano population. Ed certainly benefited from the postCivil Rights culture that was committed to providing opportunities to ethnic students who demonstrated academic aptitude and achievement. He said affirmative action programs allowed him to apply to college for free and the academic and financial support he received at college afforded him an opportunity for academic and career success.

Ed recalls his experience in school as one of success and compromise. He believes his academic achievement did not come at the expense of his ethnic identity, such as being labeled "acting White," but he did acknowledge that he consciously avoided dressing and acting in the stereotypical manner of other Chicanos. Ed believes this negotiating process was manageable because he had the mitigating factors of being an athlete and a school leader. These statuses made his experience more easily negotiable with both teachers and peers. His account of athlete status is similar to Eckert's (1989) description of the "jock/burnout" categories that she found had predisposed teachers to associate students with good/bad crowds. According to Eckert's research, teachers believed jocks displayed a middle-class orientation to school, which led them to have better relations with teachers; however, the burnouts had a working-class orientation, which led them to be invisible and forgotten. In addition, Foley (1991) would describe Ed's ability to negotiate his ethnicity with academic achievement as a "bicultural" success story. Ed was able to participate in school activities and acquire advantageous cultural capital, which helped set himself apart from other Chicano students in the eyes of his teachers.

School, as described by Ed, was the most important institution in his life and feels fortunate that at a young age his teachers decided to invest their time and effort in his academic development:

If it wasn't for the confidence they [teachers] gave me, I wouldn't have been able to further my education. ... The support from teachers was a result of me not looking like a typical Chicano even though I was one. All of my friends wanted better for themselves, certainly better than their parents, but they didn't get the ... encouragement.

In Ed's opinion, his ability to gain teacher support was the most important factor in achieving his academic goals. For all of the interviewees, their teachers were the only adults that they knew who had graduated from college. This made their teachers the most palpable source of academic support. 
Martinez: Profiles of Chicano educational opportunity 1950-1980

Profiles of Chicano Educational Opportunity

\section{Conclusions: Opportunities and Regrets in Education}

Each of the interviewees was clearly ambivalent about his/her school experiences. They all said they enjoyed school and that they valued education, but their experiences in school certainly indicated that many did not find it to be a supportive or enriching environment. As research on teacher expectation effect suggests, students are quite aware of how they are treated in the classroom, especially as high- or low-achievers, which affects how they perceive themselves and their educational possibilities (Brattesani at al., 1984; Dusek, 1985; Weinstein \& Mckown, 1998). The interview participants interpreted low teacher expectations as a lack of interest in them academically, culturally, and socially. This lack of concern forced them to consider how their ethnicity played a role in their schooling. Both consistently and subtly, the interviewees felt labeled in the classroom as at-risk, troublemaking, and uninterested in their education because of their Mexican heritage. Consequently, the lack of culturally affirming relationships with teachers hindered their ability to make connections between hard work in school and future economic and social benefits.

Ed, José, and Phillip each felt that their experiences in school were atypical of other Chicano teenagers their age, since they graduated from high school. Ed attributed the unusual experience to the fact that he excelled academically, was a leader in the classroom and the athletic field, and made strong, supportive relationships with his teachers. Although his parents supported his education, he does not believe he would have successfully transitioned to college without teacher support. Ed, José, and Phillip all believed that it was easy to get lost in the crowd if you were Chicano and a mediocre or troublemaking student. All contended that you had to "shine" to get the attention and support to graduate from high school and move on to college.

For those who did not graduate from high school, they considered their experiences in school typical of their Chicano peers. The impact of low teacher expectations played a significant role in their perception of the value of education. Today, though, they all regretted not taking academic requirements seriously and not taking advantage of their educational opportunities. For example, both Anna and Juanita contended that if they had not married early and started a family, they would have finished high school, which would have benefited themselves and their families. Furthermore, most believed that if they had worked hard in school and made the connection between academic performance and careers, they could have risen above the low expectations they encountered. They placed much of the blame on their immaturity, their lack of understanding of how schools functioned, and their ignorance of how to receive the rewards and benefits of education without compromising their ethnic identities. 
The interviewees were well aware of structural conditions, like poverty and discrimination that hindered their academic achievement. They realized that poverty complicated their academic lives because many had to work, often fulltime, and others chose to begin families of their own at an early age. Neither of these situations made their responsibilities as students easier to manage. In addition, the interviewees felt their academic abilities were underestimated because of discriminatory ideas about Chicano intelligence and occupational futures. Although the interviewees recognized structural conditions, they did not distinguish the difference between individual teachers' expectations and larger institutional barriers to their academic success. They interpreted policies, such as English-only rules and tracking, as under teacher enforcement rather than the system. Nevertheless, administrators and teachers may or may not have been aware of the multiple ways in which they constrained opportunities for Chicano students.

The interviews were valuable in providing an insight into how the teacher expectation effect can shape students' perceptions regarding the value of education and students' consequent efforts in achieving academic goals. As a result of low expectations, most interview participants questioned the need for education early on, causing them to be apathetic about school. The apathy is not surprising, given the high dropout rates among Chicano students historically and today (Garcia, 2001; Kloosterman, 2003; MacDonald, 2004; Noguera \& Wing, 2006; Valencia, 2002). The need for teacher mentorship and guidance, as well as cultural responsive practices in schools, was apparent in the interviews. Institutional policies and pedagogy can be altered, and should be, if schools are going to be seen as the democratic vehicle for social and economic mobility where children's educational interests and potentials are served.

\section{References}

Arias, M. B. (1986). The context of education for Hispanic students: An overview. American Journal of Education, 95(1), 26-57.

Babad, E., Inbar, J., \& Rosenthal, R. (1982). Pygmalion, Galatea, and the Golem: Investigations of biased and unbiased teachers. Journal of Educational Psychology, 74, 459-474.

Baron, R., Tom, D., \& Cooper, H. (1985). Social class, race, and teacher expectations. In J. B.

Dusek (Ed.), Teacher expectations (pp. 251-269). Hillsdale, NJ: Lawrence Erlbaum.

Bhattacharya, S. (1983). 'History from below.' Social Scientist, 11(4), 3-20.

Boeije, H. (2002). A purposeful approach to the constant comparative method in the analysis of qualitative interviews. Quality and Quantity, 36, 391-409.

Brattesani, K. A., Weinstein, R. S., \& Marshall, H. H. (1984). Student perceptions of differential teacher treatment as moderators of teacher expectation effects. Journal of Educational Psychology, 76, 232-247. 
Brophy, J. (1983). Research on the self-fulfilling prophecy and teacher expectations. Journal of Educational Psychology, 76, 236-247.

Buriel, R. (1981). The relation of Anglo- and Mexican-American children's locus of control beliefs to parents' and teachers' socialization practices. Child Development, 52, 104-113.

Carter, T. P. (1970). Mexican Americans in school: A history of educational neglect. New York: College Entrance Examination Board.

Carter, T. P., \& Segura, R. D. (1979). Mexican Americans in school: A decade of change. New York: College Entrance Examination Board.

Charmaz, K. (2006). Constructing grounded theory: A practical guide through qualitative analysis. Thousand Oaks, CA: Sage.

Contreras, A. R., \& Valverde, L. A. (1994). The impact of Brown on the education of Latinos. Journal of Negro Education, 63(3), 470-481.

Cortese, A. J. (1992). Family, culture, and society: Educational policy implications for Mexican Americans. Phylon, 49(1), 71-83.

Diamond, J. B., Randolph, A., \& Spillane, J. P. (2004). Teachers' expectations and sense of responsibility for student learning: The importance of race, class, and organizational habitus. Anthropology and Education Quarterly, 35(1), 75-98.

Donato, R. (1997). The other struggle for equal schools: Mexican-Americans during the civil rights era. Albany: State University of New York Press.

Donato, R. (2007). Mexicans and Hispanos in Colorado schools and communities, 19201960. Albany: State University of New York Press.

Dougherty, J. (1999). From anecdote to analysis: Oral interviews and new scholarship in educational history. The Journal of American History, 86(2), 712-723.

Dusek, J. B. (Ed.) (1985). Teacher expectations. Hillsdale, NJ: Lawrence Erlbaum.

Eckert, P. (1989). Jocks and burnouts. Social categories and identity in the high school. New York: Teachers College Press.

Fernandez, R., \& Nielsen, F. (1986). Bilingualism and Hispanic scholastic achievement: Some baseline results. Social Science Research, 15, 43-70.

Flores-Gonzalez, N. (1999). Puerto Rican high achievers: An example of ethnic and academic identity compatibility. Anthropology and Education Quarterly, 30(3), 343-362.

Foley, D. E. (1991). Reconsidering anthropological explanations of ethnic school failure. Anthropology and Education Quarterly, 22(1), 60-94.

Fordham, S., \& Ogbu, J. U. (1986). Black students' school success: Coping with the "burden of 'acting white'." The Urban Review, 18, 176-206.

Garcia, E. E. (2001). Hispanic education in the United States: Raices y alas. New York: Rowman \& Littlefield.

Glaser, B. G. (1992). Basics of grounded theory analysis. Mill Valley, CA: Sociology Press.

Goffman, E. (1963). Stigma. Notes on the management of spoiled identity. Upper Saddle River, NJ: Prentice Hall.

Gonzalez, G. G. (1990). Chicano education in the era of segregation. Cranbury, NJ: Associated University Press.

Gonzalez, G. G. (1999). Segregation and the education of Mexican-American children, 1900-1940. In J. F. Moreno (Ed.), The elusive quest for equality: 150 years of 
Chicano/ Chicana education (pp. 53-76). Cambridge, MA: Harvard Educational Review.

Hallinan, M. T. (2001). Sociological perspectives on Black-White inequalities in American schooling. Sociology of Education, 74, 50-70.

Jensen, M., \& Rosenfeld, L. B. (1974). Influence of mode of presentation, ethnicity, and social class on teachers' evaluations of students. Journal of Educational Psychology, 66, 540-547.

Jussim, L. (1991). Social perception and social reality: A reflection-construction model. Psychological Review, 98, 54-73.

Jussim, L., Eccles, J., \& Madon, S. J. (1996). Social perception, social stereotypes, and teacher expectations: Accuracy and the quest for the powerful self-fulfilling prophecy. Advances in Experimental School Psychology, 29, 281-388.

Jussim, L., \& Harber, K. D. (2005). Teacher expectations and self-fulfilling prophecies: Knowns and unknowns, resolved and unresolved controversies. Personality and Social Psychology Review, 9(2), 131-155.

Kloosterman, V. I. (2003). Latino students in American schools: Historical and contemporary views. Westport, CT: Praeger.

Laosa, L. (1977). Inequality in the classroom: Observational research on teacher-student interactions. Aztlan, International Journal of Chicano Studies Research, 8, 5167.

Lynd, S. (1993). Oral history from below. Oral History Review, 21(1), 1-8.

MacDonald, V-M. (Ed.) (2004). Latino education in the United States: A narrated history from 1513-2000. New York: Palgrave Macmillan.

Matute-Bianchi, M. E. (1986). Ethnic identities and patterns of school success and failure among Mexican-Descent and Japanese-American students in a California high school: An ethnographic analysis. American Journal of Education, 95(1), 233255.

Medina, C., \& Luna, G. (2000). Narratives from Latina professors in higher education. Anthropology and Education Quarterly, 31(1), 47-66.

Murguia, E., \& Telles, E. E. (1996). Phenotype and schooling among Mexican Americans. Sociology of Education, 69, 276-289.

Noguera, P. A., \& Wing, J. Y. (Eds.). (2006). Unfinished business: Closing the racial achievement gap in our schools. San Francisco: Jossey-Bass.

Oakes, J. (1992). Can tracking research inform practice?: Technical, normative, and political considerations. Educational Researcher, 21(4), 12-21.

Patthey-Chavez, G. G. (1993). High school as an arena for cultural conflict and acculturation for Latino Angelinos. Anthropology and Education Quarterly, 24(1), 33-60.

Pizzaro, M. (2005). Chicanas and Chicanos in school: Racial profiling, identity battles, and empowerment. Austin: The University of Texas Press.

Portes, A., \& Rumbaut, R. G. (2001). Legacies: The story of the immigrant second generation. Berkeley: University of California Press.

San Miguel, G. Jr. (1987) Let them all take heed: Mexican Americans and the quest for educational equality, 1918-1981. Austin: University of Texas Press.

San Miguel, G. Jr. (2001). Brown, not White: School integration and the Chicano Movement in Houston. College Station, TX: Texas A\&M University Press. 
Stanton-Salazar, R. D., \& Dornbusch, S. M. (1995). Social capital and the reproduction of inequality: Information networks among Mexican-origin high school students. Sociology of Education, 68, 116-135.

Thomson, A. (1998). Fifty years on: An international perspective on oral history. The Journal of American History, 85(2), 581-595.

Thomson, A. (2007). Four paradigm transformations in oral history. The Oral History Review, 34(1), 49-70.

Tollefson, J. W. (Ed.) (2002). Language policies in education: Critical issues. Mahwah, NJ: Lawrence Erlbaum.

Valencia, R. R. (2002). Chicano school failure and success: Past, present, and future (2nd ed.). New York: Routledge/Falmer Press.

Walker, C. (1987). Hispanic underachievement: Old views and new perspectives. In J. Trueba (Ed.), Failure or success? Learning and the language minority student (pp. 15-32). Cambridge, MA: Harvard Educational Review.

Weinstein, R. S., \& McKown, C. (1998). Expectancy effects in "context": Listening to the voices of students and teachers. In J. Brophy (Ed.), Advances in research on teaching (Vol. 7, pp. 215-242). Greenwich, CT: JAI. 